\title{
Fish mediate high food web connectivity in the lower reaches of a
}

\section{tropical floodplain river}

Timothy D. Jardine ${ }^{*},{ }^{,}$Bradley J. Pusey ${ }^{1}$, Stephen K. Hamilton ${ }^{2}$, Neil E. Pettit ${ }^{3}$, Peter M.

Davies $^{3}$, Michael M. Douglas ${ }^{4}$, Vivian Sinnamon ${ }^{5}$, Ian A. Halliday ${ }^{6}$, and Stuart E. Bunn ${ }^{1}$

${ }^{1}$ Australian Rivers Institute, Griffith University, Nathan, QLD, Australia

${ }^{2}$ Kellogg Biological Station and Department of Zoology, Michigan State University, Hickory Corners, MI, USA

${ }^{3}$ Cente of Excellence in Natural Resource Management, University of Western Australia, Albany, WA, Australia

${ }^{4}$ Charles Darwin University, Darwin, NT, Australia

${ }^{5}$ Kowanyama Aboriginal Land and Natural Resource Management Office, Kowanyama, QLD, Australia

${ }^{6}$ Queensland Department of Employment, Economic Development and Innovation, Brisbane, QLD, Australia

*Author for correspondence: Email - t.jardine@ griffith.edu.au, Phone +61 073735 5359, Fax +610737357615

Key words: stable sulphur isotopes, flood pulse, liver, gonad, income breeding

Authorship: TDJ wrote the manuscript and all authors provided input on earlier drafts; TDJ, BJP, SKH, and NEP performed the field sampling; PMD, MMD and SEB provided the conceptual framework and hypotheses; VS and IAH provided barramundi samples from the recreational fishery, and all authors attended a workshop to develop the project. 


\begin{abstract}
High levels of hydrological connectivity during seasonal flooding provide significant opportunities for movements of fish between rivers and their floodplains, estuaries and the sea, possibly mediating food web subsidies among habitats. To determine the degree of utilisation of food sources from different habitats in a tropical river with a short floodplain inundation duration ( 2 months), stable isotope ratios in fishes and their available food were measured from three habitats (inundated floodplain, dry season freshwater, coastal marine) in the lower reaches of the Mitchell River, Queensland (Australia). Floodplain food sources constituted the majority of the diet of large-bodied fishes (barramundi Lates calcarifer, catfish Neoarius graeffei) captured on the floodplain in the wet season and for gonadal tissues of a common herbivorous fish (gizzard shad Nematalosa come), the latter suggesting that critical reproductive phases are fuelled by floodplain production. Floodplain food sources also subsidised barramundi from the recreational fishery in adjacent coastal and estuarine areas, and the broader fish community from a freshwater lagoon. These findings highlight the importance of the floodplain in supporting the production of large fishes in spite of the episodic nature and relatively short duration of inundation compared to large river floodplains of humid tropical regions. They also illustrate the high degree of food web connectivity mediated by mobile fish in this system in the absence of human modification, and point to the potential consequences of water resource development that may reduce or eliminate hydrological connectivity between the river and its floodplain.
\end{abstract}




\section{Introduction}

Floodplain rivers of the wet-dry tropics, located throughout South America, southern Asia, Africa, and Australia, harbour some of the highest diversity of aquatic biota on the planet (Dudgeon 2000; Junk et al. 2006; Mosepele et al. 2009). Fish and other animals from these systems have historically provided protein for human populations in their catchments (Welcomme 2001). However, many of these rivers are under threat from the development of reservoirs for hydroelectric power, diversion and extraction of water for irrigation, modification of river channels for navigation, and the overarching effect of climate change (Dudgeon 2000; Tockner et al. 2008; Vörösmarty et al. 2010). All of these changes could alter the timing and magnitude of floods or remove them altogether, thus affecting the ability of aquatic animals to move between habitats to forage and serve as vectors of nutrient and organic matter transfer (i.e., subsidies for ecosystem production).

Most river ecosystem models, including the Flood Pulse Concept (Junk et al. 1989) emphasize the importance of spatial and temporal patterns of hydrologic connectivity and the resultant flux of materials and organisms between aquatic habitats and from terrestrial sources to water bodies. Many rivers have inherently low rates of primary production due to nutrient and light limitations, and secondary production can be supported by subsidies such as inputs of detritus and organisms from adjacent aquatic ecosystems (Polis et al. 1997). Maintaining the nature and extent of these subsidies is likely to be critical to the long-term sustainability of species that are reliant on them, including fish and shellfish of economic, cultural and social importance. Food web subsidies, as mediated by large, mobile consumers, have also been shown to stabilize food webs (McCann et al. 2005; Rooney et al. 2006), conferring greater resistance and resilience in the face of anthropogenic stressors including global change.

Australia's tropical river catchments are sparsely populated and the rivers remain relatively un-impacted by human activities, with only the Ord River (Western Australia) 
having a dam that withholds a substantial percentage of annual flow (Douglas et al. 2005). The lower reaches of many of these river systems have extensive floodplains and coastal wetlands, and maintain the natural hydrological connectivity to which plants and animals have adapted. Little is known about the movement of animals longitudinally (up and down river channels and between the river and its estuary) and laterally (between river and floodplain) in these systems, yet work in similar systems elsewhere-albeit with longer lasting flood pulses — suggests that these movements can represent substantial transfers of organic matter and nutrients (Winemiller and Jepsen 1998; Taylor et al. 2006).

One fish species of particular interest in tropical Australian rivers is the barramundi (Lates calcarifer) due to its commercial, recreational and cultural importance (Davis 1986), yet its life cycle remains incompletely understood. While a portion of the barramundi population completes its life cycle in saltwater (Milton et al. 2008), many young-of-the-year fish are believed to ascend onto inundated floodplains where they grow rapidly (Russell and Garrett 1983) and recruit to the recreational and commercial fisheries in fresh and brackish waters after approximately two years. A strong positive correlation between wet season discharge in any given year and the growth rates and abundance of barramundi suggests a link to floodplain inundation patterns and associated resource availability, but the reasons for this correlation remain poorly understood (Staunton-Smith et al. 2004; Robins et al. 2006).

To identify sources of production for fishes in the Mitchell River, a large floodplain river in Australia's wet-dry tropics, we took advantage of differences in the stable carbon and sulphur isotope ratios of potential basal food resources among habitats (Fry 2002; Finlay 2004). Seasonal peaks in flow and floodplain inundation in this river system are episodic and shorter than most large river systems that have been studied thus far (Junk and Wantzen 2004), and production of aquatic and semi-aquatic vascular plants is less apparent during inundation. Therefore it was not obvious at the outset of this study that the floodplain 
environments would subsidize fish production to the degree seen in rivers such as the Amazon and Orinoco of South America (see Lewis et al. 1995). As a result, we hypothesized that floodplains would make a modest contribution to the diet of fishes, particularly those captured in coastal and estuarine areas and in freshwater refugia during the dry season. To test this hypothesis, we analysed liver and muscle tissue as indicators of short- and long-term feeding, respectively, to determine whether and when fish use resources from the floodplain, marine habitats, and/or the main river (including waterholes that serve as dry season refugia for aquatic animals in channels with ephemeral flow). Simultaneous consideration of stable carbon and sulphur isotope tracers offers potential to unravel sources of food for mobile consumers that may move between river channels, floodplains, coastal wetlands, and marine waters (Fry 2002). We used this approach to determine how natural hydrologic variability and connectivity may sustain the high degree of biodiversity and fishery yields in these floodplain river systems (Bayley 1991).

\section{Materials and Methods}

\section{$\underline{\text { Study sites }}$}

The Mitchell River (141 $\left.35^{\prime} 2 \mathrm{E}-15^{\circ} 29.9^{\prime} \mathrm{S}\right)$, drains a 72,000 $\mathrm{km}^{2}$ catchment in northern Queensland, Australia, where strong wet-dry seasonality in discharge and floodplain inundation arises due to most rainfall being associated with summer monsoons and local thunderstorms over a few months. Rewetting and local flooding in the Mitchell River commonly begins in December, with full flood conditions occurring typically in January and February (Petheram et al.2008, Fig. 1). Flood duration is relatively short, with most inundation lasting less than two months in a typical year (Jardine et al. in review, Fig. 1) as opposed to many South American floodplains that are inundated for more than 3 months annually (Hamilton et al. 2002). The first year of study (2009) when the majority of data was 
collected was an above average year in terms of discharge, with peak discharges at 8 and 11 year recurrence intervals at the two most reliable gauging stations in the catchment (Fig. 1). During the dry season (March/April to October/November), most rivers flow little or cease to flow, although the main stem of the river flows all year. The transition from inundation to desiccation is rapid (Ward et al. in review), but freshwater refuges (waterholes) capable of supporting fishes persist in the deepest parts of the main river channel and tributaries, and in isolated basins on the floodplain.

$\underline{\text { Sampling for stable isotope analysis }}$

Stable isotope analysis has proven a useful tool for identifying fish migration patterns and how fish use different habitats for foraging because isotope ratios of basal resources often show distinct patterns in space and time in riverine ecosystems (MacAvoy et al. 2000, Cunjak et al. 2005). Newly arrived migrants often have a unique isotope ratio that was acquired in another location and isotope mixing models can be used to estimate the proportion of the diet derived from different sources or habitats (Phillips and Gregg 2001). Differences in turnover rates of tissues such as liver and muscle (Suzuki et al. 2005, Bucheister and Latour 2010) also allow for an estimation of diet integrated over different time scales (Quevedo et al. 2009). To fully characterize the isotopic variability of food webs in the lower Mitchell floodplain, samples were collected from a variety of locations (on-line resource Fig. S1) in the dry and wet seasons, representing the diversity of potential habitats available to fishes. Although we collected and analysed samples of primary producers (decaying leaves, emergent grasses, attached microalgae, seston) from most of these habitats including the floodplain (see Table $\mathrm{S} 1$ in supplementary material), because of the inherent spatiotemporal isotopic variability among primary producers, we instead used consumers (invertebrates and smaller fishes) as 
integrators of habitat-specific production contributing to large riverine fishes (Cabana and Rasmussen 1996).

On the floodplain during the wet season, we sampled benthic invertebrates and small fishes from a sparsely vegetated flat adjacent to Surprise Creek (Fig. S1), a distributary of the main Mitchell River that is subject to seawater or brackish tidal inflows during the dry season. This area of the floodplain is fully fresh during the wet season (conductivity $=80 \mu \mathrm{S} / \mathrm{cm}$ ), holds water longer than any other part of the floodplain, and dries completely during the dry season. Small fish were collected with seine and cast nets, and invertebrates were collected by picking from submerged surfaces (snails) and with a D-frame sweep net. Small fish from a $2^{\text {nd }}$ floodplain site adjacent to Mortol Creek (Fig. S1) were also collected using the same methods to assess among-site isotopic variability in floodplain prey. To represent the resources available to consumers in dry season freshwater habitats, invertebrates were sampled from six waterholes on the floodplain during June and October 2008 and 2009 (Fig. S1). These sites were not subjected to tidal influence and remained fresh throughout the year. To represent the marine stable isotope signature of the estuary and coastal waters, by-catch was collected from the commercial fishery. These samples were from large predators including bull sharks (Carcharhinus leucas), sawfish (Family Pristidae), king salmon (Family Polynemidae), queenfish (Scomberoides commersonianus), grunters (Pomadasys argenteus), and drum (Nibea squamosa) taken in the vicinity of the mouth of the northern branch of the Mitchell River delta (Fig. S1).

To assess contributions of different habitats to large, mobile riverine fishes we sampled the predator barramundi L. calcarifer and two common omnivorous species: catfish Neoarius graeffei, and gizzard shad Nematalosa come. These latter species are important because they compose the majority of total fish biomass in the lower reaches of many of these wet-dry tropical rivers and serve as prey for larger piscivorous fishes including barramundi 
(Pusey et al. 2004). These three species were sampled on the inundated Mitchell floodplain (Surprise Creek) during March 2009 using gill nets. In addition to the barramundi collected on the floodplain, barramundi samples were also collected from the recreational fishery throughout the dry season (April to October 2008) at various locations in the Mitchell delta (Fig. S1). To estimate the contribution of floodplain and marine production to the food web in a refugial waterhole, fish (including barramundi) were collected in the early (June) and late (October) dry season 2008 at Fish Hole Creek, a permanent freshwater body situated in the lower floodplain (Fig. S1) and their isotope ratios compared to non-mobile consumers (benthic invertebrates).

\section{Laboratory processing}

In the laboratory, white muscle was removed from larger fish while fish that were too small to extract muscle tissue were analyzed whole (minus head and guts). Benthic invertebrates were analysed as pooled samples of multiple individuals of individual species, and snails had shells removed prior to analysis to avoid contamination by shell carbonate. For the three fish species collected on the floodplain during the wet season, samples of white muscle from above the lateral line and liver tissue were dissected to provide tissues with different turnover rates for isotope analysis, as well as gonad tissue from gizzard shad to determine the source of production fuelling reproduction in this species. Samples $(n=39)$ of barramundi caught by recreational fishers during the dry season were also analysed for isotopes. Tissue samples were taken from back muscle on heads retained by traditional and recreational anglers. All tissue samples were oven-dried at $50^{\circ} \mathrm{C}$ for 48 hours and ground to a powder for isotope analysis.

Samples were weighed to approximately $0.6 \mathrm{mg}$ (carbon) and $6 \mathrm{mg}$ (sulphur) for isotope analysis. Stable nitrogen isotope data were generated alongside carbon data, but 
because of limited differences among potential foraging habitats, $\mathrm{N}$ data are used herein only for illustrative purposes to show food web structure at the permanent freshwater body (Fish Hole Creek) and to calculate source contributions to invertebrates and small fishes at the floodplain site (Table S1). Samples were combusted in an EA 3000 elemental analyser (Eurovector, Milan, Italy) and sample gases delivered to an Isoprime mass spectrometer (GV Instruments, Manchester, UK) for isotope analysis of C, N and S. Working standards were liquids calibrated against IAEA CH6, $\mathrm{CH} 7, \mathrm{~N} 1, \mathrm{~N} 2$, and NBS-127 and data are presented as parts per thousand deviations from international standards (Peedee Belemnite Carbonate, Atmospheric Nitrogen, Canyon Diablo Triolite). A sample of fish (muscle from spangled perch, Leiopotherapon unicolor) analysed repeatedly to measure precision over time yielded $\delta^{13} \mathrm{C}=-21.9 \pm 0.2 \%$ S.D. and $\delta^{15} \mathrm{~N}=5.5 \pm 0.4 \%$ S.D. $(\mathrm{n}=29)$. The precision of $\delta^{34} \mathrm{~S}$ analysis was monitored using an elemental standard (Qprawn) that had $\delta^{34} \mathrm{~S}=13.7 \pm 0.3 \%$ o S.D. $(n=21)$. The average difference between duplicate samples within runs was $0.3 \%$ and $0.4 \%$ for $\mathrm{C}$ and $\mathrm{N}$ respectively $(\mathrm{n}=97)$, and $0.7 \%$ for $\mathrm{S}(\mathrm{n}=11)$.

\section{$\underline{\text { Data analysis }}$}

All errors associated with stable isotope data are reported as 1 standard deviation (S.D.). As indicated by high $\mathrm{C} / \mathrm{N}$ mass ratios (up to 31.9), lipid content was high in liver and gonad tissue of the three large-bodied fishes. In lipid-rich tissues, available lipid-correction equations are inadequate at adjusting $\delta^{13} \mathrm{C}$ for the influence of relatively ${ }^{13} \mathrm{C}$ - depleted lipids (T.D. Jardine, unpublished data), and therefore lipids were extracted from liver and gonad samples with a chloroform-methanol solution as described in Logan et al. (2008). Lipidextracted measurements of $\delta^{13} \mathrm{C}$ are presented here for liver and gonad tissue, and all other $\delta^{13} \mathrm{C}$ data are uncorrected and unextracted because they had $\mathrm{C} / \mathrm{N}$ ratios $<4$, indicative of low lipid content. 
IsoError mixing models (Phillips and Gregg 2001) were used to calculate source proportions for the three large-bodied fishes captured on the floodplain (based on muscle and liver samples), for gizzard shad gonads, and for the barramundi muscle samples from the recreational fishery. For mixing model analyses, small fishes collected on the floodplain were used as the "floodplain" end-member because their isotope ratios were similar to non-mobile invertebrates but they provided more constrained source proportion estimates $(<100 \%)$ than when using invertebrates. The bycatch samples of predatory fishes from the commercial fishery were used as the "marine" end-member in the model. While many of these predators are themselves mobile, their isotope ratios were consistent with values for resident marine species from other studies (e.g. Van Dover et al. 1992, Gaston et al. 2004) and thus represent the marine foraging habitat. Non-mobile benthic invertebrates were used for the dry season refugia ("river") end member.

Mixing models were also used to determine source proportions for all fishes captured in the freshwater site (Fish Hole Creek) during the dry season where $\delta^{13} \mathrm{C}$ in lower trophic levels was distinct from that of available foods in floodplain and marine habitats. These latter sources (floodplain and marine) were pooled for the mixing model analysis of consumers at Fish Hole Creek (Phillips et al. 2005) because the insufficient biomass of biota from this waterhole meant $\mathrm{S}$ isotopes could not be analysed and thus a reversion to a two-source, one isotope system was necessary. Mixing model outputs for that site are therefore presented as $\%$ local (invertebrate prey from within the site) and \% external (prey from floodplain and marine habitats). Source proportions above $100 \%$ and below $0 \%$ arise from error in the estimation of mean source isotope ratios or insufficient sampling of available sources, so such values are considered indicative rather than absolute.

In all mixing model analyses, neither $\delta^{13} \mathrm{C}$ nor $\delta^{34} \mathrm{~S}$ was adjusted for trophic fractionation because the expected variation in trophic fractionation is small $( \pm 1 \%)$ relative to 
the differences among sources (McCutchan et al. 2003). $\delta^{15} \mathrm{~N}$ was not used to calculate source proportions with the exception of the Surprise Creek floodplain where an attempt was made to estimate the importance of different primary sources to invertebrates and small fishes (Table S1). In this instance a $\delta^{15} \mathrm{~N}$ trophic fractionation of 2.0\%o (McCutchan et al. 2003) was subtracted from consumer mixtures for each trophic level above primary producers and IsoSource software (Phillips and Gregg 2003) with a tolerance of $0.3 \%$ was used because there were four sources and only two isotopes ( $\mathrm{S}$ isotopes were not measured in plants).

\section{Results}

\section{$\underline{\text { Habitat-specific isotope ratios }}$}

Available food resources from the three sampling locations were isotopically distinct (Fig. S1, Fig. S2). On the Surprise Creek floodplain during the wet season, invertebrates had $\delta^{13} \mathrm{C}=-22.7 \pm 3.4 \%$ (n $\left.=24\right)$ and $\delta^{34} \mathrm{~S}=14.9 \pm 1.7 \%$ o $(\mathrm{n}=24)$. Small floodplain fishes had $\delta^{13} \mathrm{C}=-22.8 \pm 2.1 \%(\mathrm{n}=43)$ and $\delta^{34} \mathrm{~S}=13.6 \pm 1.0 \%(\mathrm{n}=45)$; these values were similar to those for small fishes from the $2^{\text {nd }}$ floodplain site at Mortol Creek $\left(\delta^{13} \mathrm{C}=-21.9 \pm 2.9 \%\right.$ and $\delta^{34} \mathrm{~S}=13.2 \pm 4.5 \% 0, \mathrm{n}=38$ ). As expected, marine fishes captured from nearby saltwater habitats had higher $\delta^{13} \mathrm{C}=-17.1 \pm 1.2 \%(\mathrm{n}=16)$ and $\delta^{34} \mathrm{~S}=19.6 \pm 0.8 \%$ o $(\mathrm{n}=15)$. Typical of freshwater environments, invertebrates from dry season freshwater sites had low and highly variable $\delta^{13} \mathrm{C}$ values $(-27.4 \pm 6.0 \%, \mathrm{n}=16)$. Compared to other freshwater systems where $\delta^{34} \mathrm{~S}$ is typically low (Fry 2002), these samples had high $\delta^{34} \mathrm{~S}(20.9 \pm 1.9 \%, \mathrm{n}=16)$. Together these sources created a suitable mixing space to estimate the proportion of consumer diet derived from each of the habitats (Fig. S2).

\section{$\underline{\text { Floodplain-captured fishes }}$}


The $\delta^{13} \mathrm{C}$ and $\delta^{34} \mathrm{~S}$ of catfish collected on the floodplain were very similar to floodplain-resident biota. Both muscle $\left(\delta^{13} \mathrm{C}=-20.5 \pm 0.9 \%\right.$ S.D., $\delta^{34} \mathrm{~S}=15.0 \pm 1.2 \%$ ) and liver $\left(\delta^{13} \mathrm{C}=-19.6 \pm 1.9 \%, \delta^{34} \mathrm{~S}=14.3 \pm 1.6 \%\right.$ ) tissue had isotope ratios that were strongly aligned with floodplain sources (Fig. 2a, Table 1). Dry season freshwaters contributed little to catfish diet (\% river based on muscle and liver $<0 \%$ ), while marine foraging was moderate for this species (30 to $40 \%$ marine based on muscle and liver, Table 1).

Mixing models suggested that key differences existed in the short and long-term diets of gizzard shad (Table 1). Muscle tissue from these fish captured on the floodplain had signatures consistent with feeding and growth in the lower reaches of the river and associated freshwaters, as well as from marine habitats $\left(\delta^{13} \mathrm{C}=-21.1 \pm 2.2 \%\right.$, $\delta^{34} \mathrm{~S}=20.6 \pm 1.2 \%$, Fig. 2b). However, liver tissue, indicative of more recent feeding, showed that these fish were indeed foraging on the floodplain $\left(\delta^{13} \mathrm{C}=-23.6 \pm 1.5 \%\right.$, $\delta^{34} \mathrm{~S}=16.4 \pm 3.0 \%$; $\%$ floodplain $=$ $59.8 \pm 13.7 \%$, Table 1). Most importantly, gonad tissue had the strongest link to the floodplain $\left(\delta^{13} \mathrm{C}=-23.3 \pm 1.3 \%\right.$ o, $\delta^{34} \mathrm{~S}=13.1 \pm 1.8 \%$; $\%$ floodplain $\approx 100 \%$, Table 1$)$, suggesting that all of the energy devoted to reproduction in this species comes from this seasonally available habitat.

Barramundi captured on the floodplain had a strong connection to floodplain prey (Fig. 2c). Similar to catfish, barramundi diet (both long- and short-term) was composed largely of floodplain food sources (muscle $\delta^{13} \mathrm{C}=-20.9 \pm 0.6 \%$ o, $\delta^{34} \mathrm{~S}=15.5 \pm 0.9 \%$; \% floodplain $=68.2 \pm 4.9 \%$; liver $\delta^{13} \mathrm{C}=-20.3 \pm 0.6 \%$, $\delta^{34} \mathrm{~S}=14.2 \pm 0.4 \%$; \% floodplain $=$ $86.4 \pm 3.2 \%$ ), with a lesser input from marine habitats (muscle $\%$ marine $=32.7 \pm 3.9 \%$; liver $\%$ marine $=30.4 \pm 4.8 \%)($ Table 1$)$

\section{$\underline{\text { Dry season food webs }}$}


Barramundi from the lower river, collected by recreational anglers throughout the dry season, derived their diet from a variable mixture of marine and floodplain habitats (Fig. 3). Isotope ratios $\left(\delta^{13} \mathrm{C}=-21.1 \pm 1.8 \%, \delta^{34} \mathrm{~S}=17.8 \pm 1.4 \%\right.$ o $)$ suggested that the major contributor was marine carbon $(\%$ marine $=45.8 \pm 5.1 \%$ ), but floodplains accounted for $34.3 \pm 4.0 \%$, despite the short inundation period of the floodplain. Some individual fishes appeared predominantly reliant on either marine or floodplain habitats (Fig. 3).

Fishes collected in Fish Hole Creek during the dry season had $\delta^{13} \mathrm{C}$ values that were up to $7 \%$ higher than those for the most ${ }^{13} \mathrm{C}$-enriched invertebrates, suggesting foraging outside of the site prior to their arrival in this refugial waterhole (Fig. 4). This was confirmed by mixing models that showed that, on average, approximately two-thirds of the fish diet in the early dry season was derived outside the site from floodplain and marine habitats (Table 2). This proportion declined to approximately one-third by late in the dry season as fish fed on local resources and approached (but did not reach) equilibrium with the isotope ratios of the local habitat (Table 2).

\section{Discussion}

Stable isotope analyses revealed differential exploitation of river, floodplain and marine habitats by the largest and most abundant fishes, and indicated that these species are adapted to take advantage of seasonally available food resources in a hydrologically variable landscape. Our observations of the importance of the ephemerally inundated floodplains are consistent with the Flood Pulse Concept that predicts an important role for the aquaticterrestrial transition zone as an area of high biological activity (Junk et al. 1989). However, in contrast to the large river floodplains that influenced the formulation of the FPC (e.g., Amazon, Mississippi), inundation in the Mitchell River system is episodic and relatively short in duration, and thus it was not obvious that the Mitchell River floodplains would subsidize 
fish production to any substantial degree. These findings highlight the strong coupling of food webs in connected habitats by large-bodied consumers (McCann et al. 2005) and suggest a high degree of stability and resistance to natural and human-induced perturbations, provided the hydrological connectivity remains intact (Rooney et al. 2006).

Not surprisingly, catfish and barramundi caught on the floodplain during the wet season derived both short- and long-term nutrition from the floodplain. The sizes of the barramundi collected were between 32 and $47 \mathrm{~cm}$ total length, indicative of fish that had been spawned only four months prior, as adult barramundi spawn in coastal areas in advance of early wet season floods in November/December. These barramundi therefore must have colonized inundated areas (Russell and Garrett 1983) and achieved rapid growth on floodplain food resources. The diet of these barramundi, based on qualitative inspection of gut contents, included plotosid catfish and other small fishes such as juvenile gizzard shad. These small fishes are known to feed on algae, detritus and small invertebrates (Pusey et al. 2004), thereby creating the rapid turnover link between seasonally-available production of attached algae and detritus (Table S1) and large bodied predatory fish.

The sampling of multiple tissues highlighted a seasonal switch in foraging patterns in gizzard shad and revealed the habitat used for critical reproductive stages. Although floodplain food sources contributed little to the long-term diet for this species as indicated by muscle tissue, they were the dominant source of carbon in recently-formed gonads, illustrating the importance of the floodplain in fuelling reproduction and classifying this species as an "income" breeder (Jonsson 1997), using readily available resources at the time of spawning to devote to development of reproductive tissue. Spawning by this species during floodplain inundation is corroborated by the presence of post-larval fish (body sizes 55 to $66 \mathrm{~mm}$ ) at the same time. Because links exist between fish foraging habitat/diet and fecundity/egg quality (Brooks et al. 1997) and the energy condition of offspring (body size, 
lipid reserves: Jardine et al. 2008), adult diet at the time of egg formation is important in ensuring that offspring get the "head start" needed to survive early life stages where mortality tends to be high (Hutchings 1991, Sogard 1997).

The importance of the floodplain was further revealed in the tissues of barramundi collected from the recreational fishery in the dry season. Even though the Mitchell floodplain is inundated for only approximately two months (Jardine et al. in review), floodplain food sources contributed on average between 30 and $40 \%$ of the diet of all barramundi in the recreational fishery, with a range among individuals of almost 0-100\% (Table 1, Fig. 3). Barramundi also migrate upstream beyond the upper limits of where collections were made in the current study, and individuals from the main channel with elevated $\delta^{13} \mathrm{C}$ indicative of floodplain and marine foraging have been observed as far as $200 \mathrm{~km}$ upriver of the delta (Hunt et al., in review), demonstrating the strong connectivity among habitats. This suggests an explanation for the link between flood magnitude and feeding and growth opportunities, partially explaining strong correlations between maximum annual river discharge and barramundi recruitment that were previously left to speculation (Robins et al. 2006).

Flood size and duration in wet-dry tropical rivers likely also affects the abundance of other species as well as preserving the constantly shifting conditions needed to support such high biomass and biodiversity in tropical rivers (Bayley 1991; Welcomme and Halls 2003). There is a strong correlation of population abundance (e.g. catch rate) or body size with river discharge for several estuarine/coastal fisheries (Loneragan and Bunn 1999; Robins et al. 2005) and for floodplain fisheries elsewhere (e.g. Niger River, Lae 1995; Bangladesh floodplains, De Graaf 2003; Amazonia, Welcomme and Halls 2003). While other mechanisms may be at play (e.g. reduced salinity promoting better growth), a large part of this variation may be explained by increased food availability in years of greater floodplain inundation. Several species of small-bodied fishes captured on the Mitchell River floodplain 
(length $<10 \mathrm{~cm}$ ) with an isotope signal similar to non-mobile invertebrates (indicative of local feeding) would be forced to move into either freshwater refugia or estuarine/coastal areas following recession of floodwaters, thereby serving as prey for predators in those food webs (Winemiller and Kelso-Winemiller 1994). These small species include spangled perch, glassfish (Ambassis sp.), ponyfish (Leioganthus equulus), barred grunter (Amniataba percoides), toothless catfish (Anodontiglanis dahli), hyrtl's tandan (Neosilurus hyrtlii), spotted scat (Selenotoca multifasciatus), Berney's catfish (Neoarius berneyi), and the aforementioned gizzard shad. The movement of these species therefore represents a food-web subsidy across ecosystem boundaries, further illustrating the implications of the high degree of hydrological connectivity in this river-floodplain system.

This study has provided evidence for a strong floodplain subsidy of riverine and estuarine food webs leading to fishes in spite of the short duration and high temporal variability of inundation. The implications for the conservation and management of wet-dry tropical floodplain systems worldwide are considerable, as future resource development scenarios are likely to involve the construction of dams and other barriers and extraction or diversion of water, diminishing the natural connectivity among habitats that appears to be a critical feature of these food webs (Dudgeon 2000; Douglas et al. 2005; Tockner et al. 2008). The first step to better management of the high degree of biodiversity found in these systems and the ecosystem services they provide is to understand the linkages between different parts of the system, and the implications of changing or eliminating those linkages. Future work should attempt to quantify flux rates of carbon carried by fishes in comparison with transport of other types of carbon (e.g. dissolved and particulate organic matter) that may greatly exceed those mediated by fish; this work will be challenging but important in this dynamic river setting. Human alteration of the hydrological connectivity between rivers and their floodplains may restrict the movements and life cycles of highly mobile consumers, 
negatively affecting recruitment and food sources for culturally and commercially valuable fish species and having repercussions that must be weighed against the benefits of human development.

\section{Acknowledgments}

The authors thank Richard Hunt, Dominic Váldez, Stephen Faggotter, Courtenay Mills, Kate Masci, Alisha Steward, Colton Perna, Michael Pusey, Raven Greenwool, Anzac Frank, Taron David, and Michael Gater for assistance with sample collection, Jeff Shellberg for hydrology data, and Rene Diocares, Vanessa Fry and Laura Jardine for help with sample processing and isotope analysis. This work was conducted under the Tropical Rivers and Coastal Knowledge (TRaCK) Research Hub. TRaCK received major funding for its research through the Australian Government's Commonwealth Environment Research Facilities initiative; the Australian Government's Raising National Water Standards Program; Land and Water Australia; the Fisheries Research and Development Corporation and the Queensland Government's Smart State Innovation Fund.

\section{Literature Cited}

Bayley PB (1991). The flood pulse advantage and the restoration of river-floodplain systems. Reg Rivers Res Manage 6: 75-86.

Brooks S, Tyler CR, Sumpter JP (1997). Quality in fish: what makes a good egg? Rev Fish Biol Fisheries 7: 387-416.

Buchheister A, Latour RJ (2010) Turnover and fractionation of carbon and nitrogen stable isotopes in tissues of a migratory coastal predator, summer flounder (Paralichthys dentatus). Canadian Journal of Fisheries and Aquatic Sciences 67:445-461 
Cabana G, Rasmussen JB (1996). Comparison of aquatic food chains using nitrogen isotopes. Proc Nat Acad Sci USA 93: 10844-10847.

Cunjak RA, Roussel JM, Gray MA, Dietrich JP, Cartwright DF, Munkittrick KR, Jardine TD (2005). Using stable isotope analysis with telemetry or mark-recapture data to identify fish movement and foraging. Oecologia 144: 636-646.

Davis TLO (1986). Migration patterns in barramundi, Lates calcarifer (Bloch) in Van Diemen Gulf, Australia, with estimates of fishing mortality in specific areas. Fish Res 4: 243258.

De Graaf G (2003). Dynamics of floodplain fisheries in Bangladesh, results of 8 years fisheries monitoring in the Compartmentalization Pilot Project. Fish Manage Ecol 10: 191-199.

Douglas MM, Bunn SE, Davies PM (2005). River and wetland food webs in Australia's wetdry tropics: general principles and implications for management. Mar Freshw Res 56: 329-342.

Dudgeon D (2000). Large-scale hydrological changes in tropical Asia: Prospects for riverine biodiversity. Bioscience 50: 793-806.

Finlay JC (2004). Patterns and controls of lotic algal stable carbon isotope ratios Limnol Oceanogr 49: 850-861.

Fry B (2002). Stable isotopic indicators of habitat use by Mississippi River fish. J N Amer Benthol Soc 21: 676-685.

Gaston TF, Kostoglidis A, Suthers IM (2004). The C-13, N-15 and S-34 signatures of a rocky reef planktivorous fish indicate different coastal discharges of sewage. Mar Freshw Res 55: 689-699.

Hamilton SK, Sippel SJ, Melack JM (2002). Comparison of inundation patterns among major South American floodplains. J Geophys Res 107(D20): art. no. 8038. 
Hunt RJ, Jardine TD, Hamilton SK, Bunn SE. In review. Temporal and spatial constraints on ecosystem metabolism and food web carbon transfer in a wet-dry tropical river. Freshwater Biology.

Hutchings JA (1991). Fitness consequenes of variation in egg size and food abundance in brook trout Salvelinus fontinalis. Evolution 45: 1162-1168.

Jardine TD, Chernoff E, Curry RA (2008). Maternal transfer of carbon and nitrogen to progeny of sea-run and resident brook trout (Salvelinus fontinalis). Can J Fish Aquat Sci 65: 2201-2210.

Jardine TD, Pettit NE, Warfe DM, Pusey BJ, Ward DP, Douglas MM, Davies PM, Bunn SE. In review. Consumer-resource coupling in wet-dry tropical rivers. Journal of Animal Ecology.

Jonsson KI (1997). Capital and income breeding as alternative tactics of resource use in reproduction. Oikos 78: 57-66.

Junk WJ, Bayley PB, Sparks RE (1989). The flood pulse concept in river-floodplain systems. In: Dodge DP (ed) Proceedings of the International Large River Symposium. Canadian Special Publication of Fisheries and Aquatic Sciences, pp. 110-127.

Junk WJ, Wantzen KM (2004). The flood pulse concept: new aspects, approaches and applications - an update. In: Welcomme RL, Petr T (eds). 2nd International symposium on the management of large rivers for fisheries FAO \& Mekong River Commission, Bangkok, Thailand.

Junk WJ, Brown M, Campbell IC, Finlayson M, Gopal B, Ramberg L, Warner BG (2006). The comparative biodiversity of seven globally important wetlands: a synthesis. Aquat Sci 68: 400-414.

Lae R (1995). Climatic and anthropogenic effects on fish diversity and fish yields in the central delta of the Niger River. Aquat Living Res 8: 43-58. 
Lewis WM, Hamilton SK, Saunders JF (1995). Rivers of northern South America. In:

Cushing CE, Cummins KW, Minshall GW (eds). River and Stream Ecosystems. Elsevier Science B.V., Amsterdam. pp. 219-256.

Logan JM, Jardine TD, Miller TJ, Bunn SE, Cunjak RA, Lutcavage ME (2008). Lipid corrections in carbon and nitrogen stable isotope analyses: comparison of chemical extraction and modelling methods. J Anim Ecol 77: 838-846.

Loneragan NR, Bunn SE (1999). River flows and estuarine ecosystems: Implications for coastal fisheries from a review and a case study of the Logan River, southeast Queensland. Aust J Ecol 24: 431-440.

MacAvoy SE, Macko SA, McIninch SP, Garman GC (2000). Marine nutrient contributions to freshwater apex predators. Oecologia 122: 568-573.

McCann KS, Rasmussen JB, Umbanhowar J (2005). The dynamics of spatially coupled food webs. Ecol Lett 8: 513-523.

McCutchan JH, Lewis WM, Kendall C, McGrath CC (2003). Variation in trophic shift for stable isotope ratios of carbon, nitrogen, and sulfur. Oikos 102: 378-390.

Milton D, Halliday I, Sellin M, Marsh R, Staunton-Smith J, Woodhead J (2008). The effect of habitat and environmental history on otolith chemistry of barramundi (Lates calcarifer) in estuarine populations of a regulated tropical river. Est Coast Shelf Sci 78: $301-315$.

Mosepele K, Moyle PB, Merron GS, Purkey DR, Mosepele B (2009). Fish, Floods, and Ecosystem Engineers: Aquatic Conservation in the Okavango Delta, Botswana. Bioscience 59: 53-64.

Petheram C, McMahon TA, Peel MC (2008). Flow characteristics of rivers in northern Australia: implications for development. J Hydrol 357: 93-111. 
Phillips DL, Gregg JW (2001). Uncertainty in source partitioning using stable isotopes. Oecologia 127: 171-179.

Phillips DL, Gregg JW (2003). Source partitioning using stable isotopes: coping with too many sources. Oecologia 136: 261-269.

Phillips DL, Newsome SD, Gregg JW (2005). Combining sources in stable isotope mixing models: alternative methods. Oecologia 144: 520-527.

Polis GA, Anderson WB, Holt RD (1997). Toward an integration of landscape and food web ecology: The dynamics of spatially subsidized food webs. Ann Rev Ecol Syst 28: 289316.

Pusey B, Kennard M, Arthington A (2004). Freshwater fishes of North-Eastern Australia. CSIRO Publishing, Collingwood, VIC.

Quevedo M, Svanback R, Eklov P (2009). Intrapopulation niche partitioning in a generalist predator limits food web connectivity. Ecology 90: 2263-2274.

Robins JB, Halliday IA, Staunton-Smith J, Mayer DG, Sellin MJ (2005). Freshwater-flow requirements of estuarine fisheries in tropical Australia: a review of the state of knowledge and application of a suggested approach. Mar Freshw Res 56: 343-360.

Robins J, Mayer D, Staunton-Smith J, Halliday I, Sawynok B, Sellin M (2006). Variable growth rates of the tropical estuarine fish barramundi Lates calcarifer (Bloch) under different freshwater flow conditions. J Fish Biol 69: 379-391.

Rooney N, McCann K, Gellner G, Moore JC (2006). Structural asymmetry and the stability of diverse food webs. Nature 442: 265-269.

Russell DJ, Garrett RN (1983). Use by juvenile barramundi, Lates calcarifer (Bloch), and other fishes of temporary supralittoral habitats in a tropical estuary in northern Australia. Aust J Mar Freshw Res 34: 805-811. 
Sogard SM (1997). Size-selective mortality in the juvenile stage of teleost fishes: A review. Bull Mar Sci 60: 1129-1157.

Staunton-Smith J, Robins JB, Mayer DG, Sellin MJ, Halliday IA (2004). Does the quantity and timing of fresh water flowing into a dry tropical estuary affect year-class strength of barramundi (Lates calcarifer)? Mar Freshw Res 55: 787-797.

Suzuki KW, Kasai A, Nakayama K, Tanaka M (2005) Differential isotopic enrichment and half-life among tissues in Japanese temperate bass (Lateolabrax japonicus) juveniles: implications for analyzing migration. Canadian Journal of Fisheries and Aquatic Sciences 62:671-678

Taylor BW, Flecker AS, Hall RO (2006). Loss of a harvested fish species disrupts carbon flow in a diverse tropical river. Science 313: 833-836.

Tockner K, Bunn SE, Gordon C, Naiman RJ, Quinn GP, Stanford JA (2008). Flood plains: criticially threatened ecosystems. In: Polunin N (ed) Aquatic Ecosystems. Cambridge University Press Cambridge, pp. 45-61.

Van Dover CL, Grassle JF, Fry B, Garritt RH, Starczak VR (1992). Stable isotope evidence for entry of sewage-derived organic material into a deep-sea food web. Nature 360: 153-156.

Vörösmarty CJ, McIntyre P, Gessner M, Dudgeon D, Prusevich A, Green P, Glidden S, Bunn SE, Sullivan C, Reidy C, Davies PM (2010). Global threats to human water security and river biodiversity. Nature 467: 555-561.

Ward DP, Hamilton SK, Jardine TD, Pettit NE, Tews EK, Olley JM, Bunn SE. In review. Assessing the seasonal dynamics of inundation, turbidity and aquatic vegetation in the Australian wet-dry tropics using optical remote sensing. Remote Sensing of the Environment. 
Welcomme RL (2001). Inland Fisheries: Ecology and Management. Food and Agriculture Organization, Blackwell Science, Oxford, UK.

Welcomme RL, Halls A (2003). Dependence of tropical river fisheries on flow. pp 267-283. In: Welcomme RL and T Petr (eds) Food and Agriculture Organization of the United Nations \& Mekong River Commission. FAO Regional Office for Asia and the Pacific, Bangkok.

Winemiller KO, Kelso-Winemiller LC (1994). Comparative ecology of the African pike, Hepsetus odoe, and tigerfish, Hydrocynus forskahli, in the Zambezi River floodplain. J Fish Biol 45: 211-225.

Winemiller KO, Jepsen DB (1998). Effects of seasonality and fish movement on tropical river food webs. J Fish Biol 53 (Suppl. A): 267-296. 
Table 1. Isoerror model output based on carbon and sulphur stable isotope ratios showing the relative contribution of floodplain, marine, and dry-season freshwater ("river") production to muscle and liver tissue of three large fish species captured in the Mitchell River, Queensland, Australia. Percentages $>100 \%$ or $<0 \%$ imply that consumers had isotope ranges outside the envelope defined by potential dietary end members and could arise from error in the isotope ratio estimates, or unidentified food sources; nonetheless, they are indicative of where the consumer lies with respect to the putative food sources.

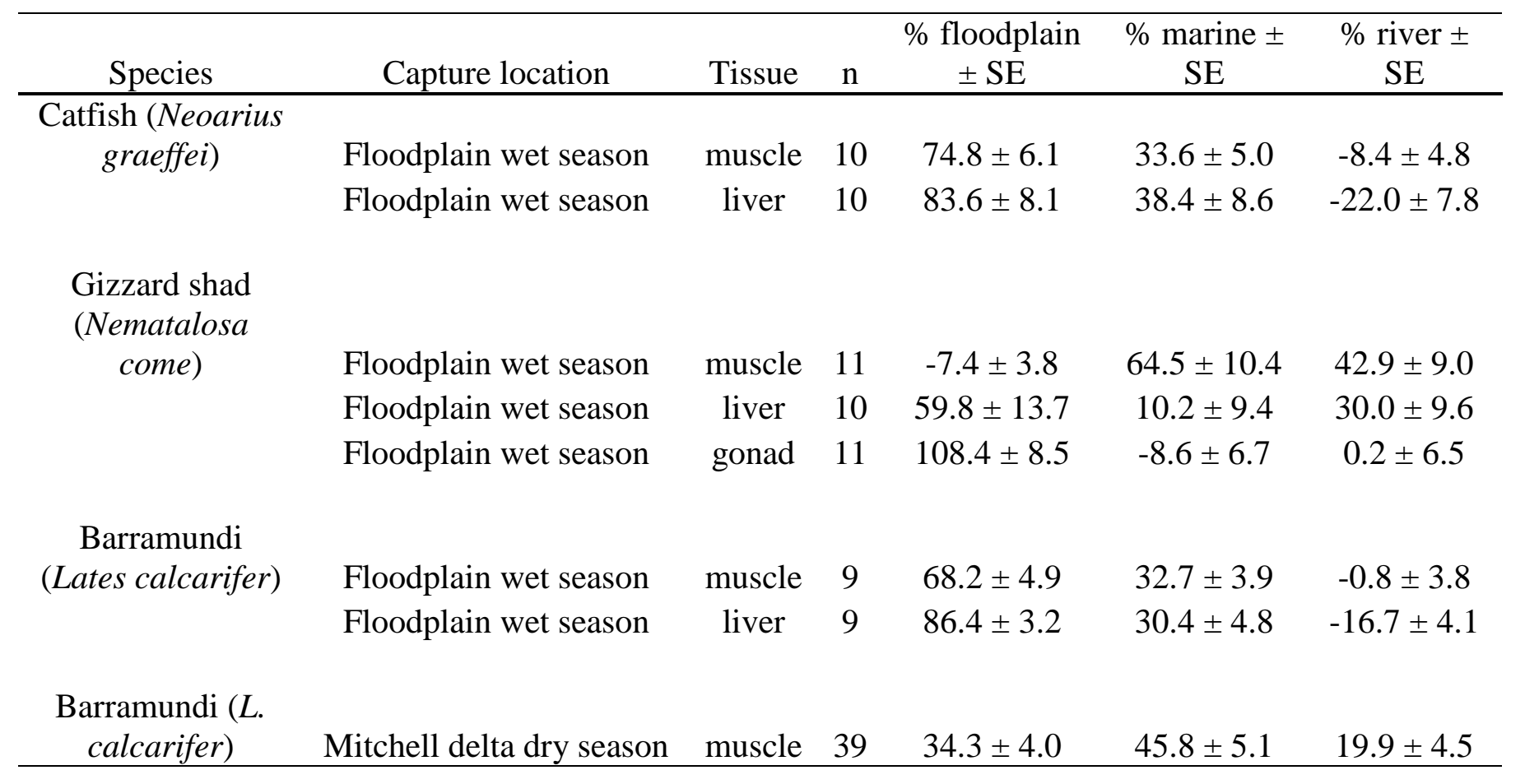


Table 2. Isoerror output showing the relative contribution of local prey (i.e., from within the waterhole) vs. external carbon sources (floodplain and marine) in muscle tissue of nine different fish species collected in Fish Hole Creek, an isolated floodplain waterhole, in the early and late dry seasons.

\begin{tabular}{|c|c|c|c|c|}
\hline Sampling time & Species & $\mathrm{n}$ & $\%$ local $\pm \mathrm{SE}$ & $\%$ external $\pm \mathrm{SE}$ \\
\hline \multirow[t]{9}{*}{ Early dry season } & Barramundi (Lates calcarifer) & 5 & $11.5 \pm 3.7$ & $88.5 \pm 3.7$ \\
\hline & Longtom (Strongylura krefftii) & 2 & $13.5 \pm 5.2$ & $86.5 \pm 5.2$ \\
\hline & Gizzard shad (Nematalosa come) & 4 & $109.6 \pm 13.0$ & $-9.6 \pm 13.0$ \\
\hline & Sleepy cod (Oxyeleotris sp.) & 3 & $26.0 \pm 4.4$ & $74.0 \pm 4.4$ \\
\hline & $\begin{array}{l}\text { Hyrtl's tandan (Neosiluris hyrtlii) } \\
\text { Rainbowfish (Melanotaenia }\end{array}$ & 2 & $52.9 \pm 19.6$ & $47.1 \pm 19.6$ \\
\hline & $\begin{array}{c}\text { splendida) } \\
\text { Snangled nerch (Leionotheranon }\end{array}$ & 1 & 40.4 & 59.6 \\
\hline & unicolour) & 3 & $14.4 \pm 7.9$ & $85.6 \pm 7.9$ \\
\hline & Saratoga (Scleropages jardinii) & 1 & -1.9 & 101.9 \\
\hline & All fish* & 8 & $33.7 \pm 13.1$ & $66.3 \pm 13.1$ \\
\hline \multirow[t]{9}{*}{ Late dry season } & Barramundi (L. calcarifer) & 3 & $50.6 \pm 12.4$ & $49.4 \pm 12.4$ \\
\hline & Longtom (S. krefftii) & 1 & 34.9 & 65.1 \\
\hline & Gizzard shad (N. come) & 1 & 143.4 & -43.4 \\
\hline & Sleepy cod (Oxyeleotris sp.) & 3 & $38.6 \pm 6.7$ & $61.4 \pm 6.7$ \\
\hline & Hyrtl's tandan (N. hyrtlii) & 3 & $44.6 \pm 11.0$ & $55.4 \pm 11.0$ \\
\hline & Rainbowfish (M. splendida) & 1 & 12.0 & 88.0 \\
\hline & Spangled perch (L. unicolour) & 2 & $21.7 \pm 16.7$ & $78.3 \pm 16.7$ \\
\hline & Glassfish (Ambassis sp.) & 2 & $143.4 \pm 15.4$ & $-43.4 \pm 15.4$ \\
\hline & All fish* & 8 & $61.4 \pm 19.4$ & $38.6 \pm 19.4$ \\
\hline
\end{tabular}

*calculated from mean of species means 


\section{Figure captions}

Figure 1. Daily discharge hydrograph for the period January 2002 to December 2009 from the lowermost gauge (Koolatah, site 919009A;

www.derm.qld.gov.au/water/monitoring/current_data/) in the Mitchell River, North Queensland, Australia, illustrating the short annual flood season associated with monsoonal rainfall

Figure 2. Isotope biplot $\left(\delta^{13} \mathrm{C}\right.$ and $\left.\delta^{34} \mathrm{~S}\right)$ of (a) catfish (Neoarius graeffei) muscle (open squares) and liver (solid squares), (b) gizzard shad (Nematalosa come) muscle (open triangles), liver (solid triangles) and gonads (shaded triangles), and (c) barramundi (Lates calcarifer) muscle (open circles) and liver (solid circles) collected on the floodplain of the Mitchell River, Queensland, Australia in 2009 and 2010. Isotope biplots of predators and prey from available habitats (marine, river, floodplain) are shown as boxes representing $1 \mathrm{SD}$ around the mean

Figure 3. Isotope biplot $\left(\delta^{13} \mathrm{C}\right.$ and $\left.\delta^{34} \mathrm{~S}\right)$ of barramundi (Lates calcarifer) muscle (open circles) collected from a variety of locations by recreational anglers (Fig. S1) during the dry season in the Mitchell River, Queensland, Australia. Isotope biplots of predators and prey from available habitats (marine, river, floodplain) are shown as boxes representing 1 SD around the mean

Figure 4. Isotope biplot $\left(\delta^{13} \mathrm{C}\right.$ and $\left.\delta^{15} \mathrm{~N}\right)$ of consumers in Fish Hole Creek, an isolated freshwater body on the Mitchell River floodplain in the (a) early and (b) late dry season. Solid symbols are invertebrates (diamonds - mayflies Ephemeroptera, squares - dragonflies Odonata, circles - prawns Macrobrachium spp.), other symbols are fish (open diamonds longtom, open triangles - sleepy cod, open squares - spangled perch, open circles rainbowfish, x's - barramundi, +'s - hyrtl's tandan, X's - gizzard shad) 
Figure 1.

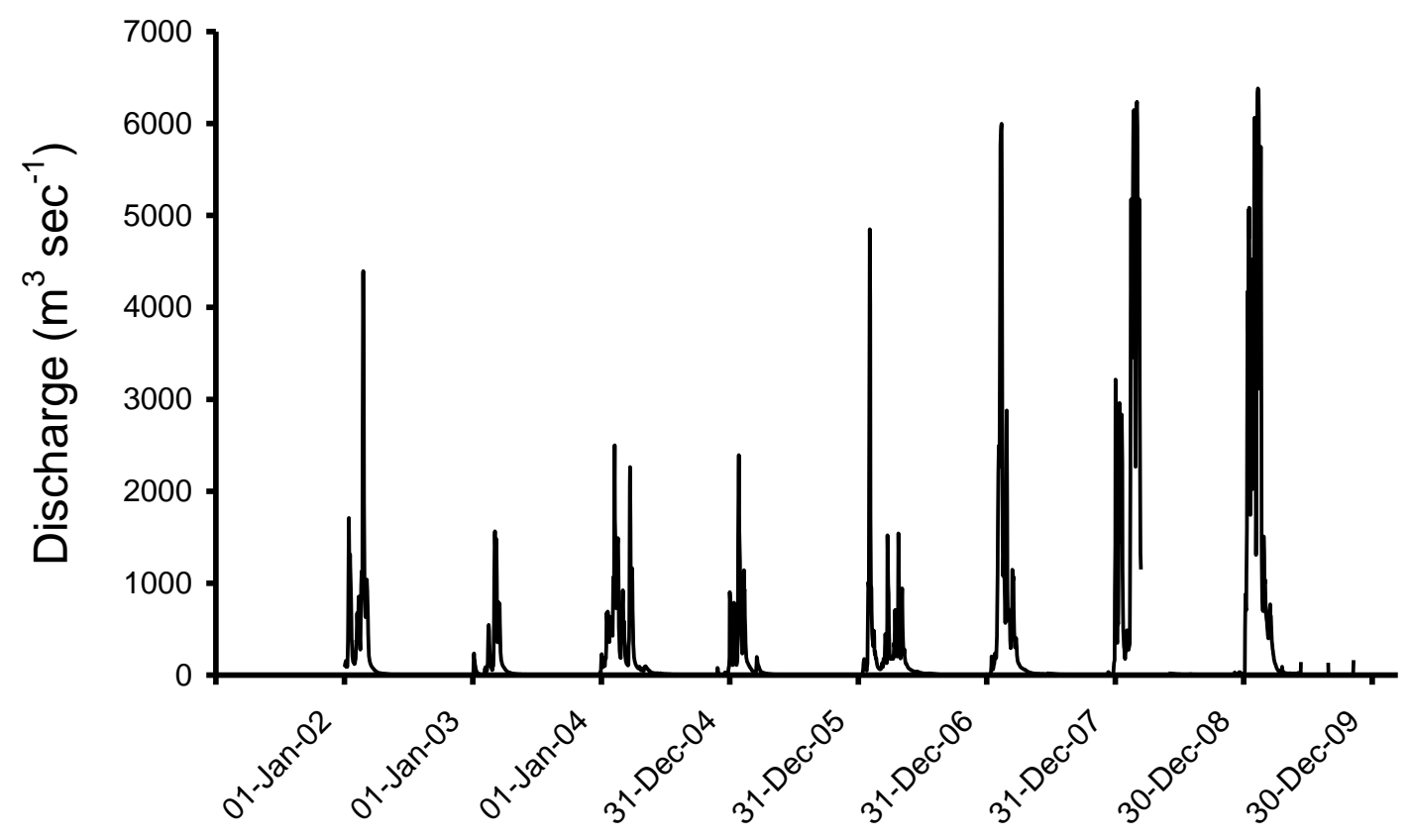


Figure 2.
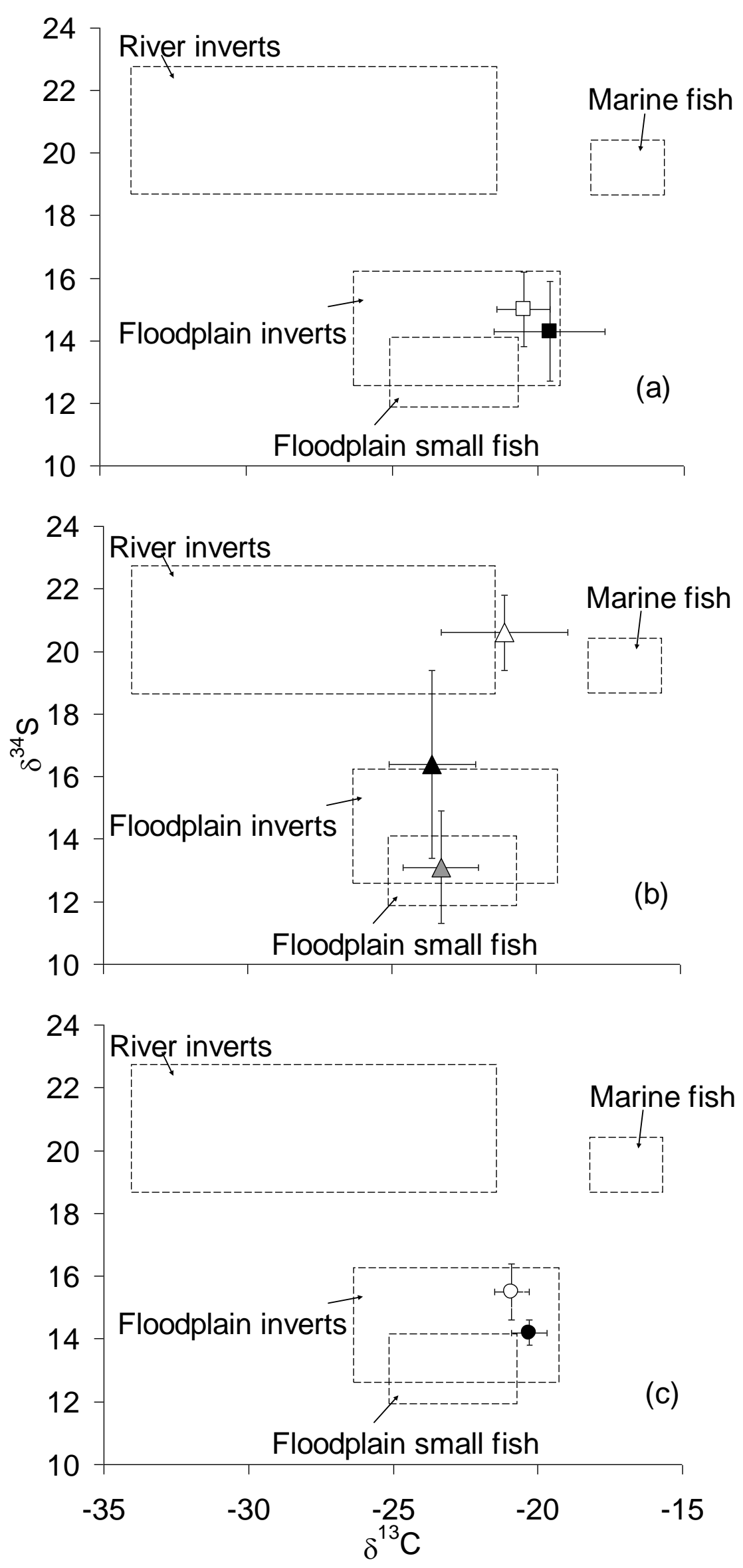
Figure 3.

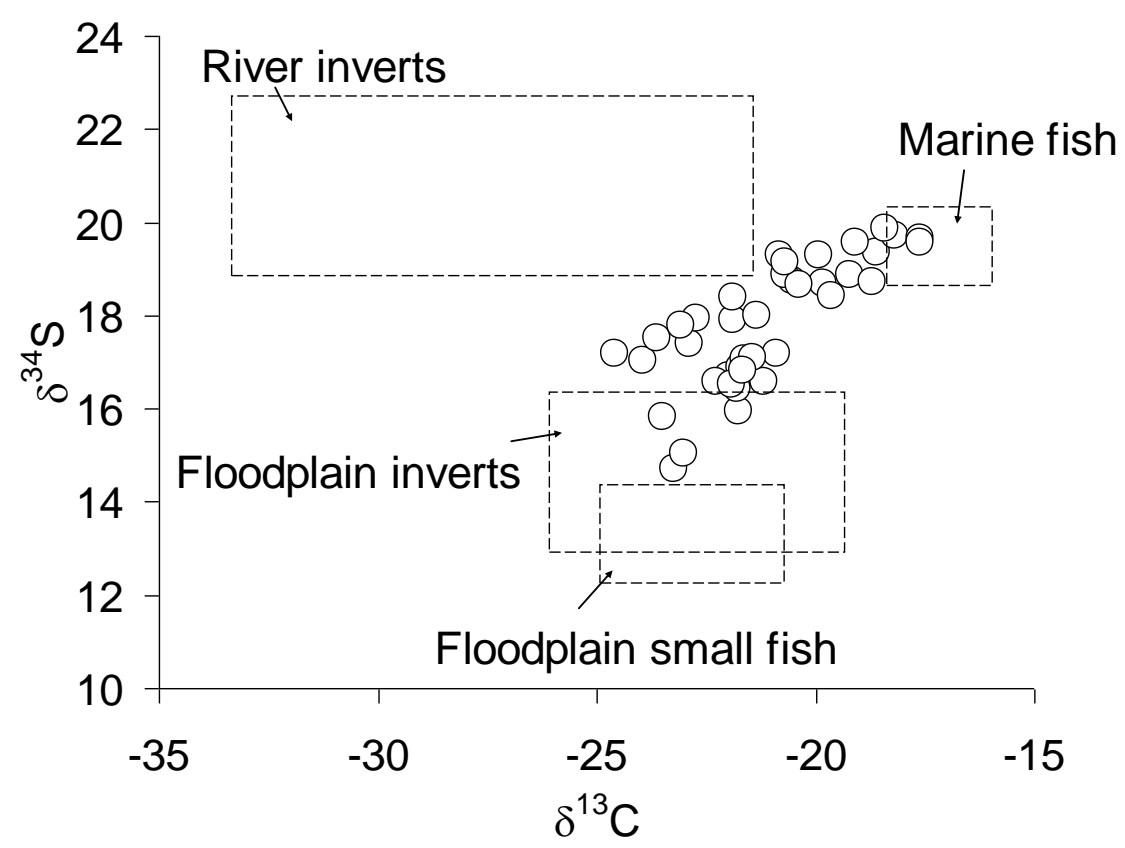


Figure 4.

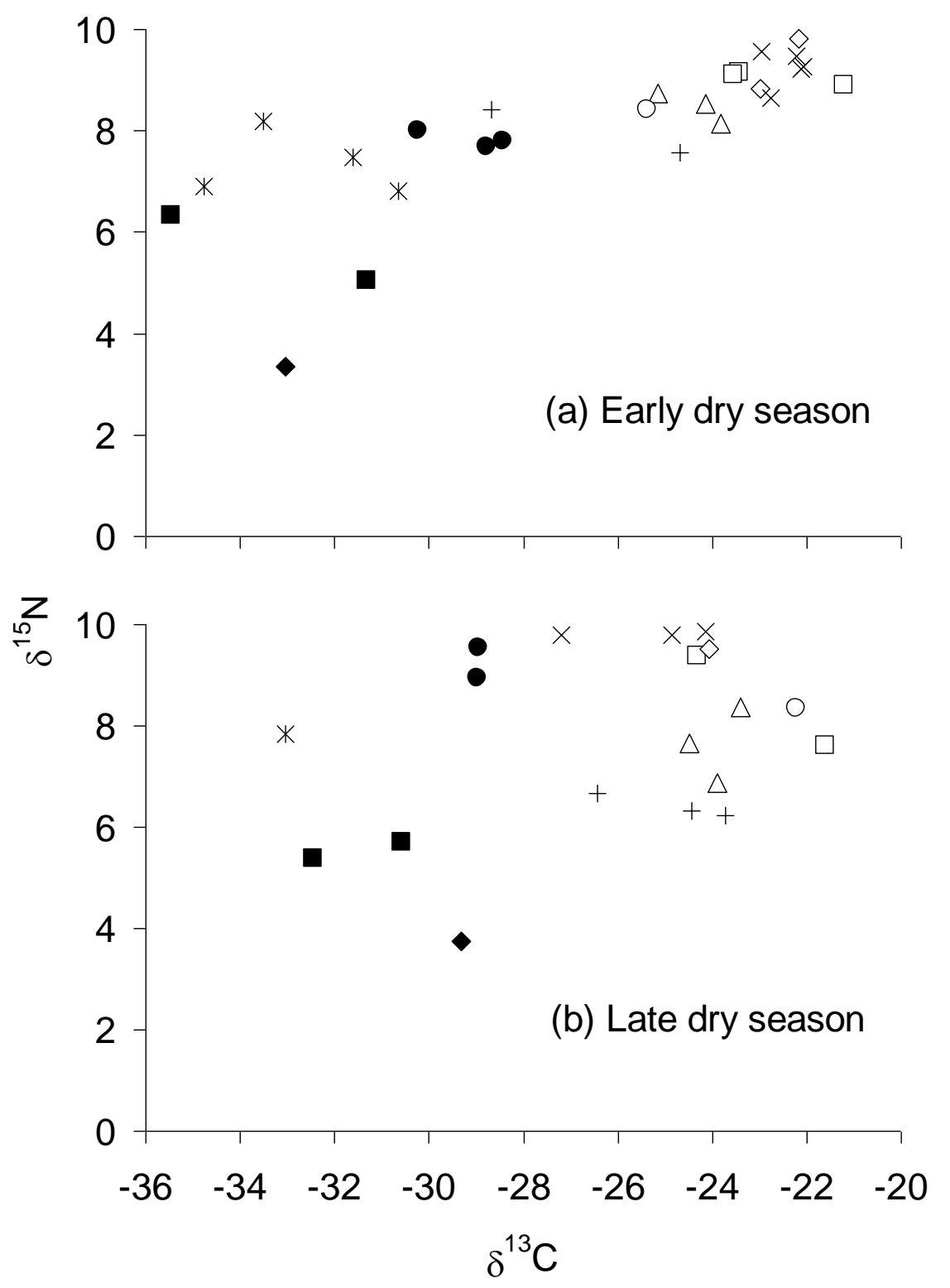

